\title{
Are all professional investors sophisticated?
}

\author{
Lukas Menkhoff, Leibniz Universität Hannover, Germany, \\ Maik Schmeling, Leibniz Universität Hannover, Germany, and \\ Ulrich Schmidt, University of Kiel, Germany
}

\author{
Discussion Paper No. 397 \\ May 2009 (revised) \\ ISSN 0949-9962
}

\begin{abstract}
Existing empirical evidence is inconclusive whether professional investors show more sophisticated behavior than individual investors. Therefore, we study two important groups of professional investors and compare them to laymen by way of a survey covering about 500 investors. We find that some professionals, i.e. institutional investors, behave more sophisticated than laymen, whereas the less researched investment advisors seem to do even worse. Our survey approach complements available evidence due to its design: it compares professionals to (qualified) interested laymen, it covers six measures of sophisticated behavior, uses several control variables and strictly compares investment decisions in the private domain.
\end{abstract}

JEL-Classification: G 1, D 80

Keywords: Institutional investors, investment advisors, individual investors, investment behavior

We would like to thank all those investors who participated in the survey underlying this research. Moreover, we thank participants at several university seminars and a Bundesbank conference for helpful comments, in particular Peter Bofinger, Helga Fehr-Duda, Werner Güth, Hans-Helmut Kotz, Renate Schubert, Alois Stutzer and an anonymous referee.

Lukas Menkhoff, Department of Economics, Leibniz Universität Hannover, Königsworther Platz 1, D-30167 Hannover, Germany, menkhoff@gif.uni-hannover.de; Maik Schmeling, schmeling@gif.uni-hannover.de; Ulrich Schmidt, uschmidt@bwl.uni-kiel.de 


\section{Are all professional investors sophisticated?}

\section{Introduction}

Sophisticated behavior of some investors - presumably professional investors - is a necessary condition for financial markets to function efficiently. Unfortunately, not only individual investors but also professionals are plagued by "biased" behavior as demonstrated by excessive turnover (Dow and Gorton, 1997), home bias (Strong and Xu, 2003), loss aversion (Coval and Shumway, 2005) and herding (Sias, 2004). Thus a more modest examination of functioning markets asks whether professionals behave more sophisticated than individual investors. We contribute to this strand of literature by comparing two kinds of professionals, i.e. institutional investors and investment advisors, with laymen in a unified approach. Interestingly, we find that these two kinds of professionals are different: whereas institutional investors behave more sophisticated than laymen, investment advisors seem to do even worse.

Our study differs from most earlier related research due to distinguishing between two groups of professionals and also due to its empirical design as a survey study. It covers almost 500 investors and has characteristics of a "framed field experiment" in the sense of Harrison and List (2004). ${ }^{1}$ Whereas laboratory experiments and conventional empirical analyses generate "hard" data, the survey approach has other advantages which motivate its use. In comparison to conventional laboratory experiments it targets those who really act in financial markets. Moreover, the careful design of the questionnaire as

\footnotetext{
${ }^{1}$ Out of the six factors discussed by Harrison and List (2004) defining field experiments, it is "the nature of the stakes" which is necessarily artificial in a questionnaire study as there is no financial incentive. However, meaningful financial incentives for financial professionals will blow up research budgets anyway.
} 
well as its distribution through a professional intermediary aim for providing a representative environment for respondents (Levitt and List, 2007). This is often seen as decisive to get unbiased answers (List, 2006). In comparison to the study of trading data our approach has three advantages:

First, we address the concern that evidence in behavioral finance often seems eclectic (e.g. Shiller, 1999). Accordingly, we examine the impact of professionalism on six measures of sophisticated investment behavior. This is the avoidance of five biases which can be seen as stylized and costly facts of financial markets - excessive turnover (Barber and Odean, 2000), home bias (Lewis, 1999), reluctance to loss realization (Odean, 1998), the disposition effect (Shapira and Venezia, 2001) and herding - and forecasting ability.

Second, we carefully control the possible impact of professionalism by a set of variables indicating sophisticated behavior including "investment experience" (e.g. Dorn and Huberman, 2005, Feng and Seasholes, 2005, for individuals, Menkhoff et al., 2006, for professionals), "wealth" of investors (Vissing-Jørgensen, 2003) and their "risk aversion" (Dorn and Huberman, 2005). Finally, the survey approach allows considering further important control variables, such as age, the degree of education, the seniority of position reached and investors' attitudes.

Third, we seek for evidence without interference from other determinants of investment decisions, such as incentives or transaction costs, by explicitly asking in the questionnaire about "private investment decisions". We know for example: institutional investors have higher turnover than individual investors (e.g. Carhart, 1997), they invest less at home (Grinblatt and Keloharju, 2001), they sell assets easier conditional on capital losses (Grinblatt and Keloharju, 2001a) and they do take profits better (Shapira and Venezia, 2001). However, these studies compare institutionals' job behavior with individu- 
als' private behavior, so that differences between groups are distorted by different transaction costs and incentives in addition to professionalism. Thus, higher turnover or less home bias may be the outcome of lower transaction costs, high turnover may be due to portfolio churning (Dow and Gorton, 1997) and willingness to sell may be driven by “window dressing" as well (Lakonishok et al., 1991).

Our study belongs to a strand of research which compares the behavior of (1) institutional investors and (2) investment advisors to individual investors. Earlier studies on (1) have found: institutional investors rely more on fundamental information (Shiller and Pound, 1989), they show a better performance (Grinblatt and Keloharju, 2000, Barber and Odean, 2008, indirectly Stotz, 2006) and respond more rationally towards news (Cohen et al., 2002). However, professionals are not always "superior" investors. Institutional and individual investors channel money towards mutual funds that subsequently perform well (Keswani and Stolin, 2008). Institutional investors show more positive feedback herding than individual investors (Dennis and Strickland, 2002), professionals show more myopic los aversion than students (Haigh and List, 2005) and professional traders can be more overconfident than students (Glaser et al., 2007). By contrast, there is less research which compares investment advisors to laymen, i.e. comparison (2). Shapira and Venzia (2001) show advisors' superiority in that they have better diversified portfolios, a smaller disposition effect and slightly higher profits. Bluethgen et al. (2008) and Gerhardt and Hackethal (2009) confirm enhanced diversification of portfolios which are advised. However, investment advisors may also have less wanted effects, such as increased fee expenses (Bluethen et al., 2008), too much equity in customer portfolios (Jansen et al., 2008) and higher trading activity (Gerhardt and Hackethal, 2009). 
As we compare professionals to laymen our research is related to but different from a growing literature on financial literacy (e.g. Lusardi and Mitchell, 2006, Müller and Weber, 2008, Calvet et al., 2009). These studies typically examine the impact that (various indicators of) financial knowledge has on financial decisions, such as investment decisions. Some of the indicators used for literacy - such as wealth, experience, risky assets (Calvet et al., 2009) - show up in our study as control variables in order to carve out the effect from professionalism sharply.

These references allow for more precisely relating to the literature the comparisons we make in our study. First, we examine two kinds of professionals in one approach which includes the so far less researched investment advisors. They seem to be less professional on average than institutional investors because of their job profile: their customers are less qualified in financial terms, they have to deal with more clients, they do not have access to first hand information (but get financial information from the bank's headquarter) and they usually earn a lower salary than institutional investors. Second, we compare professionals to interested laymen. This is different from average laymen or students because such less interested investors will be either marginal in that they have little to invest or if they have significant private funds they will tend to buy investment advice.

The paper proceeds in the following way. Section 2 gives information on the data. Descriptive results on measures of sophisticated investment behavior are presented in Section 3, whereas Section 4 considers controls in the multivariate approach. Economic significance and robustness is presented in Section 5 and conclusions are discussed in Section 6 . 


\section{Data}

This section shows that the data set is useful to serve our research purpose. The data are by and large reliable (Section 2.1) and they are representative for relevant investor groups (Section 2.2).

\subsection{Data compilation}

The data employed here have been compiled to examine our research questions. Data come from an online survey of German investors conducted from $4^{\text {th }}$ to $11^{\text {th }}$ November 2004 in cooperation with sentix ${ }^{\circledR}$.

The latter is a large German online platform where registered investors reveal their expectations concerning relevant financial and economic indicators and asset prices on a weekly basis. As a reward for their participation, users can view results of the surveys and market analyses based on these surveys provided by the operators of sentix. Thus, sentix users do not represent average but highly committed individual investors. ${ }^{2}$ Moreover, due to their commitment, we expect investors to understand the questionnaire well and to respond carefully. We used this platform to distribute our own survey questionnaire and received a total of 497 responses during the above-mentioned week in November 2004. The absolute response is thus in the same dimension as the number of active participants during the first two weeks in November 2004 (475 and 509 respondents respectively) which equals a response rate of about $25 \%$ of all users.

Since the survey is anonymous we asked participants to indicate whether they are individual investors, investment advisors or institutional investors. Our 497 responses are

\footnotetext{
${ }^{2}$ The online survey among registered users is anonymous and voluntary. Registration is necessary to ensure prudent behavior at the platform and is not restricted otherwise. More details can be inferred via www.sentix.de.
} 
made up of 75 institutional investors, 78 investment advisors and 344 individual investors. This self-indication of respondents can be cross-checked with the database of sentix ${ }^{\circledR}$, which contains information about the affiliation of investors with professional financial institutions such as banks, asset managers, or insurance companies. So we can be sure that participants did not indicate themselves as professionals although they are not. The platform provider has also more detailed information about affiliations which is, however, not available to us. Due to the registration at this platform, the provider controls that each respondent answers the questionnaire only once.

Often-voiced concerns regarding survey data are that participants do not fully understand all questions, that they answer strategically or that they randomly answer without thinking about the questions. However, none of these objections seems to be a problem in this online survey. First, we conducted a pretest to ensure understandable wording and relevant questions. Nevertheless, investors did not have to answer all questions if they did not like to or if they did not understand the questions. Second, since the questionnaire was anonymous and announced to be used for academic purposes only, there does not seem to be an incentive for strategic answering. Strategies aiming for a distortion of the overall level of answers were useless ex ante due to the large number of participants addressed; this disincentive has proved to be credible because of the many responses realized. Third, since participants in our survey are registered users of sentix ${ }^{\circledR}$ and take part in the weekly questionnaire voluntarily, it can be expected that they are highly interested in financial market research and have an intrinsic motivation to answer correctly.

Overall, the data seem to be as reliable as can be expected for a survey questionnaire. Further insights can be gained from analyzing participants attributes. 


\subsection{Participants' objective attributes}

This section shows objective attributes of participants, such as age, education etc., which allows comparisons with other data sets describing investors. We find that our sample is by and large representative for our target investor groups.

The average investor of our survey is about 40 years old, has roughly 12 years of investment experience, has earned a university degree, is male, occupies a senior position, privately invests a securities volume of about 250 thousand Euros and holds an equity share of $40 \%$. Therefore, we have a sample of well-qualified investors (details are provided in Table 1$)^{3}$

Investor groups differ in some characteristics to a statistically significant degree. Individual investors are older than the two other groups, have the shortest investment experience (despite their highest age) and occupy most senior positions on average (possibly reflecting their higher age). Investment advisors' experience is different from institutional investors as there are more persons with shorter experience as well as more persons with very long experience. Finally, institutional investors are most wealthy, indicated by the investors' private portfolio volume (significant at the $10 \%$ level). Unfortunately, the low variance of "gender" here does not allow us to include this item in any regression.

Many of these attributes have been compiled in earlier survey studies on institutional investors in Germany and show that our sample is similar to them (see Menkhoff et al., 2006 and sources therein). Regarding individual investors, demographic information about survey respondents from a June 2000 survey of a German online broker's clients (Dorn and Huberman, 2005) matches our data quite well; our data is also similar to the

\footnotetext{
${ }^{3}$ We also use these personal characteristics as control variables because they are related to investment behavior (e.g. Agnew et al., 2003, Vissing-Jørgensen, 2003, Graham et al., 2005, Menkhoff et al., 2006, Karlsson and Nordén, 2007).
} 
UBS/Gallup participants studied by Graham et al. (2005). When we compare our individual investors, however, with the total investor population in Germany, it becomes obvious that our sample is distorted towards more qualified individual investors (see data in Dorn and Huberman, 2005).

In summary, our sample of investors in Germany is quite representative of institutional investors but reflects characteristics of highly-qualified individual investors. Thus, the difference between groups is narrower than in the full population which heightens the stakes to find any effect by professionalism on investment behavior.

\section{Descriptive information about investors' behavior}

This section provides information about investors' self-stated behavior, covering measures of sophisticated behavior (Section 3.1) and further variables which are used as controls (Section 3.2).

\subsection{Measures of sophisticated behavior}

The examination of sophisticated investment behavior relies on six measures. Some of these measures indicate biased behavior and should thus be avoided by sophisticated investors, which is, however, not found in our sample.

Our first measure of sophisticated behavior is the avoidance of excessive turnover. For this measure we relate portfolio turnover to portfolio volume (see item 1 in Table 2). Participants choose between four categories, where long-term buy and hold investors would select category 1 or possibly 2 , whereas investors with a clear tendency towards portfolio churning would fall into categories 3 and 4 accordingly. In fact, our investors tend towards portfolio churning as only about $10 \%$ of them belong to the category with 
very low turnover and another $30 \%$ to the next category. $60 \%$ of our investors, however, have a turnover rate of more than $25 \%, 40 \%$ are even above $50 \%$. Figure $1 \mathrm{~A}$ gives the frequency distribution for the groups of investors, showing that institutional investors behave least biased. $30 \%$ of institutional investors, $40 \%$ of investment advisors and $43 \%$ of individual investors have an annual turnover of more than 50\%. Assuming a rather conservative midpoint of $75 \%$ for the highest turnover category, the mean turnover rates for these three investor groups are roughly $38 \%, 44 \%$ and $45 \%$ respectively. ${ }^{4}$ We will use these four categories of increasingly higher turnover as our measure of portfolio churning.

We are aware that this is an imprecise measure because there may be very different motivations for transactions, such as pure liquidity motives or private information. However, the same criticism would also apply to a statistical figure being derived from bank accounts and is thus a price that has to be paid when analyzing turnover. The only way out of this problem would be information about trading success. Wermers (2000) shows in this respect that high turnover of mutual funds can be justified.

Our second measure of sophisticated behavior is the avoidance of home bias. We ask participants to allocate an amount of $10,000 €$ to five world regions (see item 2 in Table 2). The share being invested in Germany, i.e. in the domestic country, is the figure of interest which is undistorted by any regulatory requirements that effectively limit for example pension funds to invest abroad. Only about $4 \%$ of these investors prefer a German investment share of up to $5 \%$. The mean value of home investment is $29.6 \%$ and the median is still $20 \%$. Figure 1B gives the frequency distribution of preferred domestic in-

\footnotetext{
${ }^{4}$ A typical turnover figure for institutional investors is about 70 to $80 \%$ (e.g. Carhart, 1997). Turnover figures for individual investors seem to depend on investor and portfolio type. For example, investors with an online broker show very high turnover, such as roughly $75 \%$ p.a. (Barber and Odean, 2000, p.775) for a US case, contrasted by the figure from US single 401(k) pension investments with turnover of 16\% (Agnew et al., 2003, p.194).
} 
vestment share for the groups of institutional investors, investment advisors and individual investors are $19.2(17.5), 31.8$ (25.0) and 31.5 (20.0) for the mean (median) respectively. This preference contrasts with Germany's share in world stock market capitalization of $3-5 \%$ only, depending on the type of securities considered. So, investment shares of $10 \%$ and more, as they characterize the preferences of about $90 \%$ of investors, tentatively indicate a home bias. Accordingly, we simply take the share being invested in Germany grouped into six categories - as the degree of home bias. Again, this is an imprecise measure because there may be investors who in fact have information advantages about the German market and thus rationally invest there. However, examinations of portfolios do not indicate that home bias in general has this rational foundation.

As our third measure of sophisticated investment we take avoidance of reluctance to loss realization. This is the degree of approval to the statement that an investor usually waits for a price recovery instead of selling those securities in case of a loss position (see item 3 in Table 2). In theory, there is no reason to wait for a price recovery which is simply an orientation on past prices. In reality, however, the frequency distribution of answers in Figure 1C indicates that investors tend to behave reluctantly to realize losses: $30 \%$ of the respondents rather agree with the statement and less than $25 \%$ completely disapprove. The figure also directly visualizes the difference between investor groups: whereas $40 \%$ of individual investors and even $43 \%$ of investment advisors rather agree with the statement, only $28 \%$ of institutional investors do so.

The fourth measure of sophisticated behavior is avoidance of the disposition effect. This effect is approximated by item 4 in Table 2, i.e. the preference to sell profitable assets in case of liquidity demand. Again, there is no theoretical reason to do so, nevertheless, investors are plagued by this behavior (e.g. Dhar and Zhu, 2006). Interestingly, there 
is some evidence that institutional investors are less affected by the detrimental disposition effect than individual investors (Shapira and Venezia, 2001). The answers in our sample indicate that the disposition effect applies to all kinds of investors to a relevant degree, although somewhat less to institutional investors (see Figure 1D).

As a fifth measure of sophisticated behavior we employ a proxy for herding. The survey approach has the advantage of identifying herding - and distinguishing it from common reaction on the same fundamental information - by asking directly for trend following behavior (see item 5 in Table 2). About $60 \%$ say to conform to this approach which contradicts conventional theoretical expectations of rational behavior. However, theoretical models show that in a rational expectations equilibrium, past prices may be informative for an asset's value when some traders have private information (see e.g. early Grundy and McNichols, 1989). Moreover, from a purely empirical point of view, it is well-known that trend-following momentum strategies are profitable (Jegadeesh and Titman, 2001) and may be thus less surprising that asset managers tend to apply these strategies (e.g. Grinblatt et al., 1995). It seems thus interesting to note that institutional investors tend more towards trend following behavior than other investors (see Figure 1E).

Finally, the sixth measure of sophisticated behavior is straight forward because we ask for stock indices return forecasts. The survey includes two forecasts, on the expected German stock index DAX and the US stock index Dow Jones, both one month ahead (see item 6 in Table 2). One has to concede, of course, that these are just two cases where respondents can proof their sophistication and thus the outcome can be heavily influenced by accidental and unforeseen events. Indeed, due to extremely strong index up-movements at that time we restrict our analysis to simple directional forecasts. Only about one half of all 
investors expected an increase of both indices. Nevertheless, Figure 1E shows that institutional investors are tentatively better than others, although at a slight margin.

Overall, our descriptive analysis of sophistical investment behavior indicates that all investors seem to be biased to a significant degree. While this applies to both laymen and professional investors, it can also be seen that all professionals are not alike: institutional investors are less biased than laymen whereas investment advisors are not.

\subsection{Further control variables}

Investment behavior may be influenced by further investor attitudes which we introduce in two groups, one reflecting more general influences, the other being specific to the home bias phenomenon.

To control the importance of professionalism, two variables of general relevance are included (see items 7 and 8 in Table 2). First, the general attitude regarding risk aversion in professional investment decisions is asked for (see Dorn and Huberman, 2005). Second, a long-term forecasting horizon when making investment decisions may influence behavior and is thus elicited (Klos et al., 2005). Investors in our survey classify themselves as being somewhat less risk averse than the hypothetical average investor (detailed responses are documented in Table 3). Finally, the investors' forecast horizon is distributed around "2-6 months" as the median and modus; individual investors have the relatively shortest horizon.

The last two variables, local information advantage and return optimism, are relevant as determinants of home bias only (see Lütje and Menkhoff, 2007, and literature discussion therein). Obviously, the belief in a domestic information advantage (see item 9 in Table 3) is not so strong because answers tend slightly towards contradiction than ap- 
proval. Interestingly, individual investors believe least in a domestic information advantage and investment advisors most. In item 6, investors are asked to give their return expectation for Germany's leading stock market index, the DAX, because a higher share of investments at home would make sense if return optimism were higher too. However, return expectations of respondents are distributed around zero. Note that differences within groups are large whereas differences between the three groups are not statistically significant. Tentatively, home bias is positively related to return optimism in our sample, reflecting the finding that home bias is also related to - unrealistic - return optimism among institutional investors (Strong and $\mathrm{Xu}, 2003$ ).

Up to this point of analysis, lessons from descriptive statistics show how different investors between and within groups are, how much most of them are plagued with biased behavior and how diverse differences between financial professionals and laymen are. These complex relations provide a strong motivation to perform multivariate regressions. This is done in the following section.

\section{$4 \quad$ Regression analyses}

We find that professionalism only sometimes is a robust correlate of more sophisticated investment behavior. After a note on methods in Section 4.1, we show results for the six measures of sophisticated behavior in Section 4.2. 


\subsection{Methods applied}

The data generated by the survey are available in different forms which require appropriate regression techniques each. To account for heteroscedasticity, all statistical inference is based on robust standard errors. ${ }^{5}$

In most cases we employ ordered probit regressions to account for the ordered, discrete nature of our response variables. This applies to four measures of sophisticated investment behavior as responses were given according to four or six categories: turnover, reluctance to loss realization, disposition effect and trend following. As responses to the question of home investments are available as percentage shares we employ a censored linear regression for this dependent variable where the censoring takes place at an investment share of zero and one hundred percent (since it may the case that investors actually want to short or buy the asset on margin, respectively). Finally, in order to test directional forecasting ability for the DAX and Dow Jones we rely on simple bivariate probit regressions.

As a robustness check, we reestimate the home bias variable in parallel to other measures via an ordered probit regression. The dependent variable is then a categorical transformation of our domestic investment variable, since this original variable lies in the interval $[0,1]$ and is thus not necessarily well captured by linear regression models or even Tobit models (when censoring at $0 \%$ or $100 \%$ does not indicate investors' desire to short or to leverage). We make use of the ordered nature of our data and form six different categories: $[0,10),[10,30),[30,50),[50,70),[70,90),[90,100]$. The two smaller categories in the left-hand and right-hand margins are used to capture the observed extreme realizations

\footnotetext{
${ }^{5}$ We have also run all following regressions with standard errors based on a bootstrap with 250 repetitions. Results are very similar to those reported in the following.
} 
of home bias. Using this ordered approach does not impact qualitative results, however (results are available on request).

\subsection{Correlates of sophisticated investment behavior}

This section analyzes results from regressions on the above introduced six measures of sophisticated behavior. These regressions include all relevant variables that have been discussed in Section 2.

Starting with turnover, column (1) in Table 4 shows regression results for "explaining" turnover. Institutional investors have significantly lower turnover - i.e. less excessive turnover - than the two other groups. Further variables being related to lower turnover include higher age, longer experience, better education and a longer horizon. However, there are also variables "increasing" turnover, i.e. more wealth and willingness to accept a higher investment risk. These results are similar to those found in Dorn and $\mathrm{Hu}$ berman (2005, Table 9). ${ }^{6}$

The regression results for our second measure, home bias, are given in column (2) of Table 4. Surprisingly, the coefficient signs for the two groups of professionals are different: institutional investors show less home bias than individual investors whereas investment advisers have a significantly higher degree of home bias. Furthermore, we find that older and less experienced investors show more home bias, longer horizons are related to less home bias and, finally, that the belief of a domestic information advantage leads to a larger home investment share.

\footnotetext{
${ }^{6}$ They also find experience, knowledge (in our study: education), wealth and risk aversion to explain turnover as we do. Moreover, they find men and overconfident investors to exhibit more turnover, variables which cannot be used in our sample, whereas we find occupation and forecasting horizon to be significant, two variables that are not included in Dorn and Huberman
} 
The fact that older investors prefer home assets compared to younger ones has been found by Karlsson and Nordén (2007) and Lütje and Menkhoff (2007) before. However, further correlations which were found to be important by Karlsson and Nordén (2007) are not significant in the extended approach here. This refers to share of equities, higher wealth and also to better education and more senior position. ${ }^{7}$ It is reassuring that the "information advantage" variable which is among the best-established correlates of home bias according to earlier studies also shows up significantly here (although here it is a subjective measure only). This is despite the different method for data compilation, the questionnaire survey, and despite many more control variables that are included here compared to earlier work.

The results on reluctance to loss realization are given in column (3) of Table 4. Again, institutional investors respond differently from individual investors to a statistically significant degree. Also the response of investment advisors is tentatively the same as for home bias, as they again tend to be more biased than individual investors, although at a significance level of only $14 \%$. There is one more variable "explaining" less reluctance to loss realization, i.e. being more experienced. Overall, explanatory power is comparatively weak.

This also applies to our fourth measure, i.e. a response in accordance with the disposition effect. The regression result in column (4) of Table 4 shows that investor groups do not differ in this respect. By contrast, "wealth" is the most significant variable in rela-

(2005). The only variable that comes out somewhat differently is age, which loses significance in Dorn and Huberman (2005) when they use a larger set of controls.

${ }^{7}$ In order to come closer to a replication of Karlsson and Nordén (2007), we have run a regression explaining individual investors' home bias solely by these personal characteristics. We find that in this case investment volume (as a proxy for wealth) significantly reduces home bias. 
tion to a reduced disposition effect (see also Dhar and Zhu, 2006), followed by experience, the latter at the $10 \%$ significance level.

Investor groups become important again at the next measure of sophisticated behavior, i.e. trend following. Column (5) in Table 4 shows that institutional investors - but not investment advisors - apply this strategy to a significantly higher degree than individual investors. This appears a bit surprising having the conventional wisdom in mind that trend following is not oriented towards fundamentals and thus indicates unsophisticated behavior. However, whatever the reason is, empirical evidence and theoretical arguing shows - as mentioned above - that trend following may be profitable and a fully rational strategy. The degree of trend following is also related to being older but less experienced, holding a higher equity share, being more risk averse and having a shorter investment horizon.

Finally, as another simple sophistication measure, we examine directional return forecasts. Column (6) for the German stock index DAX and column (7) for the US stock index Dow Jones show that these two cases of forecasting cannot be well explained. The reason is probably extremely high volatility at the time of forecasting, i.e. in 2003. Accordingly only those investors with low risk aversion - indicating among others their optimism - are mostly correct in predicting the realized upwards movement in stock prices. Investors groups are less relevant as institutional investors do not forecast particularly well (at that time), whereas investment advisors made significantly worse forecast about the US index compared to individual investors.

In summary and comparing results on these various measures of sophisticated investment behavior there emerges a clear pattern: being a financial professional does not seem enough to bring about behavior generally more sophisticated than that of advanced 
individual investors. Rather some professionals, i.e. institutional investors, behave less biased than individual investors, whereas other professionals, i.e. investment advisors, behave the same as individual investors or even more biased.

It also seems interesting to note that in our sample which includes a large set of relevant control variables, the variable "investment experience" also has a quite clear relation to a more rational investment behavior. This relation holds in addition to being an institutional investor and thus obviously covers another important aspect of more sophisticated behavior. Contrarily, "wealth" and "risk aversion" do not provide much additional insight in understanding investment behavior, at least not in our sample of relatively advanced investors.

\section{$5 \quad$ Economic significance and robustness}

This section rounds up our main findings by addressing some potential concerns. We proceed in three steps, first showing that findings are not only statistically significant but also economically relevant, second demonstrating that it is important to distinguish financial professionals in our sample into two groups and third checking that a stepwise exclusion of insignificant control variables does not qualitatively impact our results.

In order to investigate the economic significance of our results, we show marginal effects for being an institutional investor and an investment advisor, respectively. Most of our regression models (except for the home bias censored regression model) do not allow a direct interpretation of the estimated coefficients so that an analysis of this kind seems useful. We base the calculation of marginal effects on the specifications shown in Table 4 although we only report the effects for the two occupation dummies to conserve space Marginal effects are calculated at variable medians and results are shown in Table 5. Be- 
ing an institutional investor increases the probability of being in one of the "low turnover categories" (i.e. $x \leq 25 \%$ p.a.) - which has an unconditional probability of about $34 \%-$ by more than 11 percentage points. This can be seen by adding the first two entries in the table corresponding to the "institutional investors" variable (i.e. $5.12+6.23=11.35 \approx$ $11 \%$ ). Thus, the marginal effect is roughly $33 \%$ of the unconditional probability, which clearly is of economic significance. Results are not always as impressive for the further measures but nevertheless they are not negligible. In short, being an institutional investor decreases the probability of being in the three categories with the highes reluctance to loss realization by about $9 \%$ (unconditional probability: $38 \%$ ), increases the probability of being in the three categories with the highest disposition effect by only $1 \%$ (unconditional probability: 49\%), being in the three highest trend following categories by $13 \%$ (unconditional probability: $60 \%$ ). Contrary to these figure for institutional investors, being an investment advisors increases the probability of being reluctant to loss realization by $8 \%$ and the probability of a high disposition effect by $6.5 \%$ whereas there is no real effect on trend following.

Finally, for the directional forecasts, being an institutional investor increases the likelihood of a correct DAX forecast direction by roughly $6 \%$ and decreases the likelihood of a correct DJ forecats direction by $3.5 \%$. Being an advisor has no significant effect on the DAX forecast but reduces the probability of a correct DJ forecast by almost $14 \%$. Therefore, relative to each other, institutionals clearly outperform advisors in the forecasting exercises.

To prove the importance of distinguishing financial professionals into two groups we rerun the above regression from Table 4 but merge institutional investors and investment advisors into one group. Results on this new variable show unanimously that pro- 
fessionalism tends to have the expected influence on some variables but that it is never statistically significant at the $10 \%$ level (results available on request). This underlines that it is not professionalism as such that drives results and it makes even more plausible why we may often find inconclusive results in the literature.

Finally, to make sure that our findings are not driven by a fortunate constellation of included explanatory variables in the regressions, we start with the results presented in Table 4 and exclude all variables that are not significant at the $10 \%$ level. Main findings are not qualitatively affected by the inclusion or exclusion of some variables (results available on request).

\section{Conclusions}

Recent studies have found that professionals do not necessarily behave sophisticated in financial markets. We follow a strand of research which examines the potential inefficiency in behavior by comparing professionals to laymen. Our approach is different from most papers in two directions: first, we do not take one group of professionals but we add investment advisors to the more often considered institutional investors. Second, we compare professionals to interested laymen, arguing that they are more relevant in financial markets than for example students.

Our survey of about 500 German investors complements available evidence from trade data and laboratory experiments by providing evidence similar to a framed field experiment. It serves to examine the impact of various measures of sophisticated investment behavior to overcome more electic evidence, it controls for a large set of variables suggested in the literature and it compares professionals and laymen on an equal basis, i.e. regarding their private investment decisions. 
We find clear evidence that there is one group of professionals, i.e. institutional investors, which behaves more sophisticated than laymen, whereas other professionals, i.e. investment advisors, seem to do even worse. Whereas the role of institutional investors is in line with most of earlier findings, the role of investment advisors is less clear. Results seem to suggest that investment advisors may often not be able to give useful advice and existing incentives may not always be helpful (Jansen et al., 2008, Güth et al., 2008). However, the benchmark here are interested laymen and it is well possible that these qualified laymen are not the target group of investment advisors. Accordingly, when investment advisors work for average laymen they may still be able to improve portfolio diversification as other papers have shown. This does not, preclude, however, that there is room for improved training of investment advisors (Nosic and Weber, 2009).

On some minor issues we find that investment experience is related to improved behavior, in addition to being an institutional investor. Wealth and risk aversion, however, do not seem to be equally important. Finally, our approach highlights that it is important to compare professionals and laymen in a truly uniform way, as institutional investors trade more heavily than individual investors when examining their job behavior but they trade less when both groups are compared on their private investments. 


\section{References}

Agnew, Julie, Pierluigi Balduzzi and Annika Sundén (2003), Portfolio Choice and Trading in a Large 401(k) Plan, American Economic Review, 93:1, 193-215.

Barber, Brad M. and Terrance Odean (2000), Trading Is Hazardous to Your Wealth: The Common Stock Investment Performance of Individual Investors, Journal of Finance, 55:2, 773-806.

Barber, Brad M. and Terrance Odean (2008), All that Glitters: The Effect of Attention and News on Buying Behavior of Individual and Institutional Investors, Review of Financial Studies, 21:2, 785-818.

Bluethgen, Ralph, Andreas Gintschel, Andreas Hackethal and Armin Müller (2008), Financial Advice and Individual Investors' Portfolios, SSRN Working Paper 968197.

Calvet, Laurent E., John Y. Campbell and Paolo Sodini (2009), Measuring the Financial Sophistication of Households, NBER Working Paper 14699.

Carhart, Mark M. (1997), On Persistence in Mutual Fund Performance, Journal of Finance, 52, 57-82.

Cohen, Randolph B., Paul A. Gompers and Tuomo Vuolteenaho (2002), Who Underreacts to Cash-flow News? Evidence from Trading between Individuals and Institutions, Journal of Financial Economics, 66, 409-462.

Coval, Joshua D. and Tyler Shumway (2005), Do Behavioral Biases Affect Prices?, Journal of Finance, 60:1, 1-34.

Dennis, Patrick J. and Deon Strickland (2002), Who Blinks in Volatile Markets, Individuals or Institutions?, Journal of Finance, 57:5, 1923-1949.

Dhar, Ravi and Ning Zhu (2006), Up Close and Personal: Investor Sophistication and the Disposition Effect, Management Science, 52, 726-740.

Dorn, Daniel and Gur Huberman (2005), Talk and Action: What Individual Investors Say and what They Do, Review of Finance, 9:4, 437-481.

Dow, James and Gary Gorton (1997), Noise Trading, Delegated Portfolio Management, and Economic Welfare, Journal of Political Economy, 105, 1024-1050.

Feng, Lei and Mark S. Seasholes (2005), Do Investor Sophistication and Trading Experience Eliminate Behavioral Biases in Financial Markets?, Review of Finance, 9, 305-351.

Gerhardt, Ralf and Andreas Hackethal (2009), The Influence of Financial Advisors on Household Portfolios: A Study on Household Portfolios: A Study on Private Investors Switching to Financial Advice, SSRN Working Paper 1343607.

Glaser, Markus, Thomas Langer and Martin Weber (2007), On the Trend Recognition and Forecasting Ability of Professional Traders, Decision Analysis, 4:4, 176-193.

Graham, John R., Campbell R. Harvey and Hai Huang (2005), Investor Competence, Trading Frequency, and Home Bias, NBER Working Paper 11426.

Grinblatt, Mark and Matti Keloharju (2000), The Investment Behavior and Performance of Various Investor-Types: A Study of Finland's Unique Data Set, Journal of Financial Economics, 55, 589-616.

Grinblatt, Mark and Matti Keloharju (2001), How Distance, Language, and Culture Influence Stockholdings and Trade, Journal of Finance, 56:3, 1053-1073.

Grinblatt, Mark and Matti Keloharju (2001a), What Makes Investors Trade?, Journal of Finance, 56, 589-616. 
Grinblatt, Mark, Sheridan Titman and Russ Wermers (1995), Momentum Investment Strategies, Portfolio Performance, and Herding: A Study of Mutual Fund Behavior, American Economic Review, 85:5, 1088-1105.

Grundy, Bruce and Maureen McNichols (1989), Trade and Revelation of Information through Prices and Direct Disclosure, Review of Financial Studies, 2, 495526.

Güth, Werner, M. Vittoria Levati and Matteo Ploner (2008), The Impact of Payoff Interdependence on Trust and Trustworthiness, German Economic Review, 9, 8795.

Haigh, Michael S. and John A. List (2005), Do Professional Traders Exhibit Myopic Loss Aversion? An Experimental Analysis, Journal of Finance, 60:1, 523-534.

Harrison, Glenn W. and John A. List (2004), Field Experiments, Journal of Economic Literature, 42:4, 1009-1055.

Jansen, Christian, René Fischer and Andreas Hackethal (2008), The Influence of Financial Advice on the Asset Allocation of Individual Investors, EFA2008 Athens Meetings Paper.

Jegadeesh, Narasimhan and Sheridan Titman (2001), Profitability of Momentum Strategies: An Evaluation of Alternative Explanations, Journal of Finance, 56, 699720.

Karlsson, Anders and Lars Nordén (2007), Home Sweet Home: Home Bias and International Diversification among Individual Investors, Journal of Banking and Finance, 31:2, 317-333.

Keswani, Aneel and David Stolin (2008), Which Money Is Smart? Mutual Fund Buys and Sells of Individual and Institutional Investors, Journal of Finance, 63:1, 85118.

Klos, Alexander, Elke U. Weber and Martin Weber (2005), Investment Decisions and Time Horizon: Risk Perception and Risk Behavior in Repeated Gambles, Management Science, 51:12, 1777-1790.

Lakonishok, Josef, Andrei Shleifer and Robert W. Vishny (1991), Window Dressing by Pension Fund Managers, American Economic Review, 81:2, 227-231.

Levitt, Steven D. and John A. List (2007), Viewpoint: On the Generalizability of Lab Behaviour to the Field, Canadian Journal of Economics, 40:2, 347-370.

Lewis, Karen K. (1999), Trying to Explain Home Bias in Equities and Consumption, Journal of Economic Literature, 37, 571-608.

List, John A. (2006), Field Experiments: A Bridge between Lab and Naturally Occurring Data, B.E. Journal in Economic Analysis \& Policy, 6:2, Advances Article 8.

Lütje, Torben and Lukas Menkhoff (2007), What Drives Home Bias? Evidence from Fund Managers' Views, International Journal of Finance and Economics, 12:1, 21-35.

Lusardi, Annamaria and Olivia S. Mitchell (2008), Financial Literacy and Planning: Implications for Retirement Wellbeing, updated SSRN Working Paper 881847.

Menkhoff, Lukas, Ulrich Schmidt and Torsten Brozynski (2006), The Impact of Experience on Risk Taking, Overconfidence and Herding of Fund Managers: Complementary Survey Evidence, European Economic Review, 50, 17531766.

Müller, Sebastian and Martin Weber (2008), Financial Literacy and Mutual Fund Investments: Who Buys Actively Managed Funds?, SSRN Working Paper 1093305. 
Nosic, Alen and Martin Weber (2009), How Risky Do I Invest: The Role of Risk Attitudes, Risk Perceptions and Overconfidence, SSRN Working Paper 1004002.

Odean, Terrance (1998), Are Investors Reluctant to Realize their Losses?, Journal of Finance, 53, 1775-1798.

Shapira, Zur and Itzhak Venezia (2001), Patterns of Behavior of Professionally Managed and Independent Investors, Journal of Banking and Finance, 25, 1573-1587.

Shiller, Robert J. (1999), Human Behavior and the Efficiency of the Financial System, in: John B. Taylor and Michael Woodward (eds.), Handbook of Macroeconomics, 1, 1305-1346.

Shiller, Robert J. and John Pound (1989), Survey Evidence on Diffusion of Interest and Information Among Investors, Journal of Economic Behavior and Organization, 12:1, 47-66.

Sias, Richard W. (2004), Institutional Herding, Review of Financial Studies, 17:1, 165206.

Stotz, Olaf (2006), Germany's New Insider Law: The Empirical Evidence after the First Year, German Economic Review, 7:4, 449-462.

Strong, Norman and Xinzhong Xu (2003), Understanding the Equity Home Bias: Evidence from Survey Data, Review of Economics and Statistics, 85:2, 307-312.

Vissing-Jørgensen, Annette (2003), Perspectives on Behavioral Finance: Does "Irrationality" Disappear with Wealth? Evidence from Expectations and Actions, NBER Macroeconomics Annual, 18, 139-194.

Wermers, Russ (2000), Mutual Fund Performance: An Empirical Decomposition into Stock-Picking Talent, Style, Transaction Costs, and Expenses, Journal of Finance, 55, 1655-1703. 
Figure 1. Distribution of indicators of sophisticated investment behavior
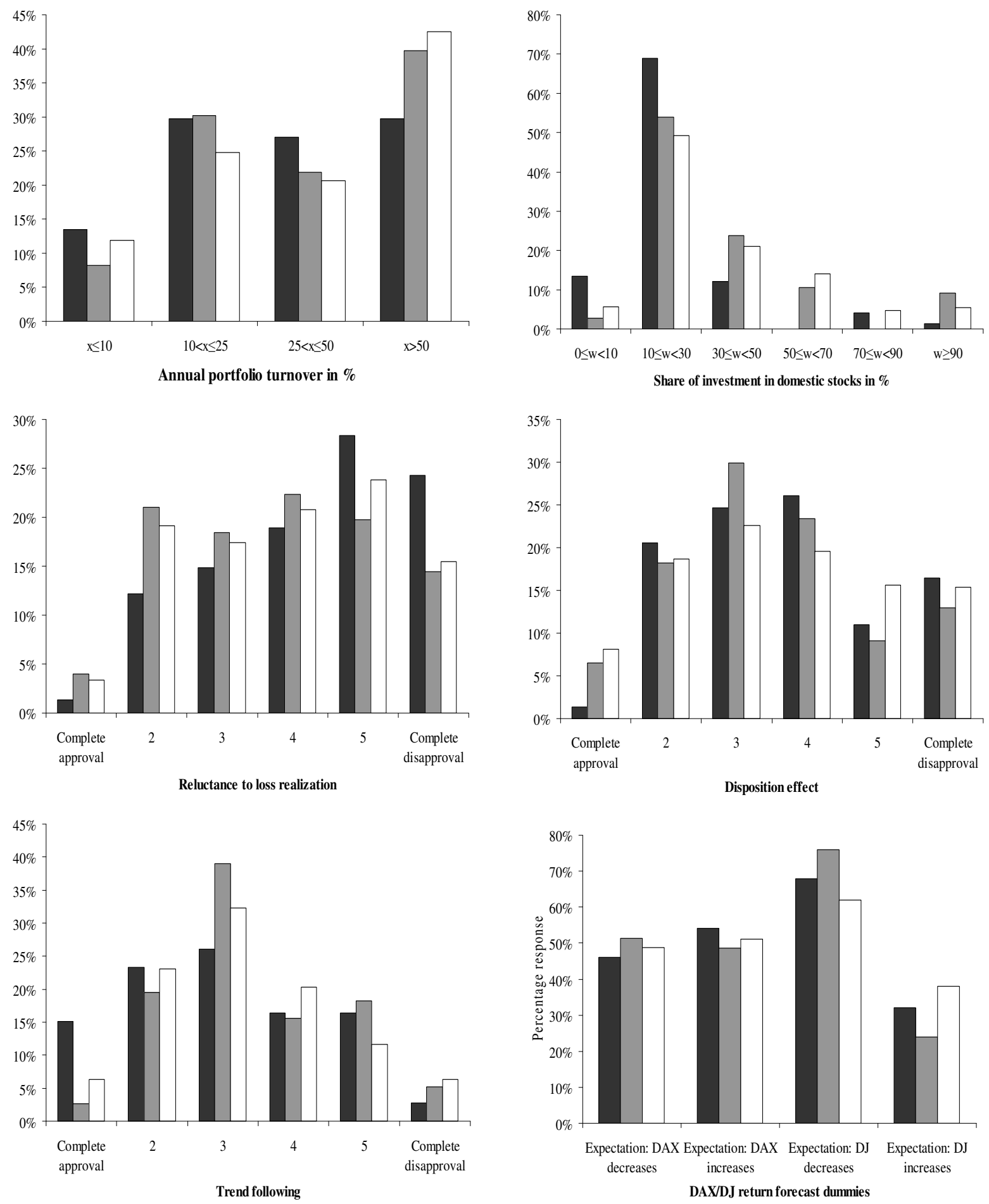

Notes: Black bars show responses of institutional investors, grey bars are for investment advisors, and white bars are for individual investors. Each subfigure shows the percentage response of all three investor groups to a certain questionnaire item addressing a measure of sophisticated behaviour each. For example, in one survey question investors could choose between 4 categories of annual portfolio turnover (upper left panel). Here, almost $15 \%$ of institutional investors answered "less than 10\%" (first category) whereas roughly 30\% answered "more than 50\%" (fourth category). 
Table 1. Survey participants' objective attributes

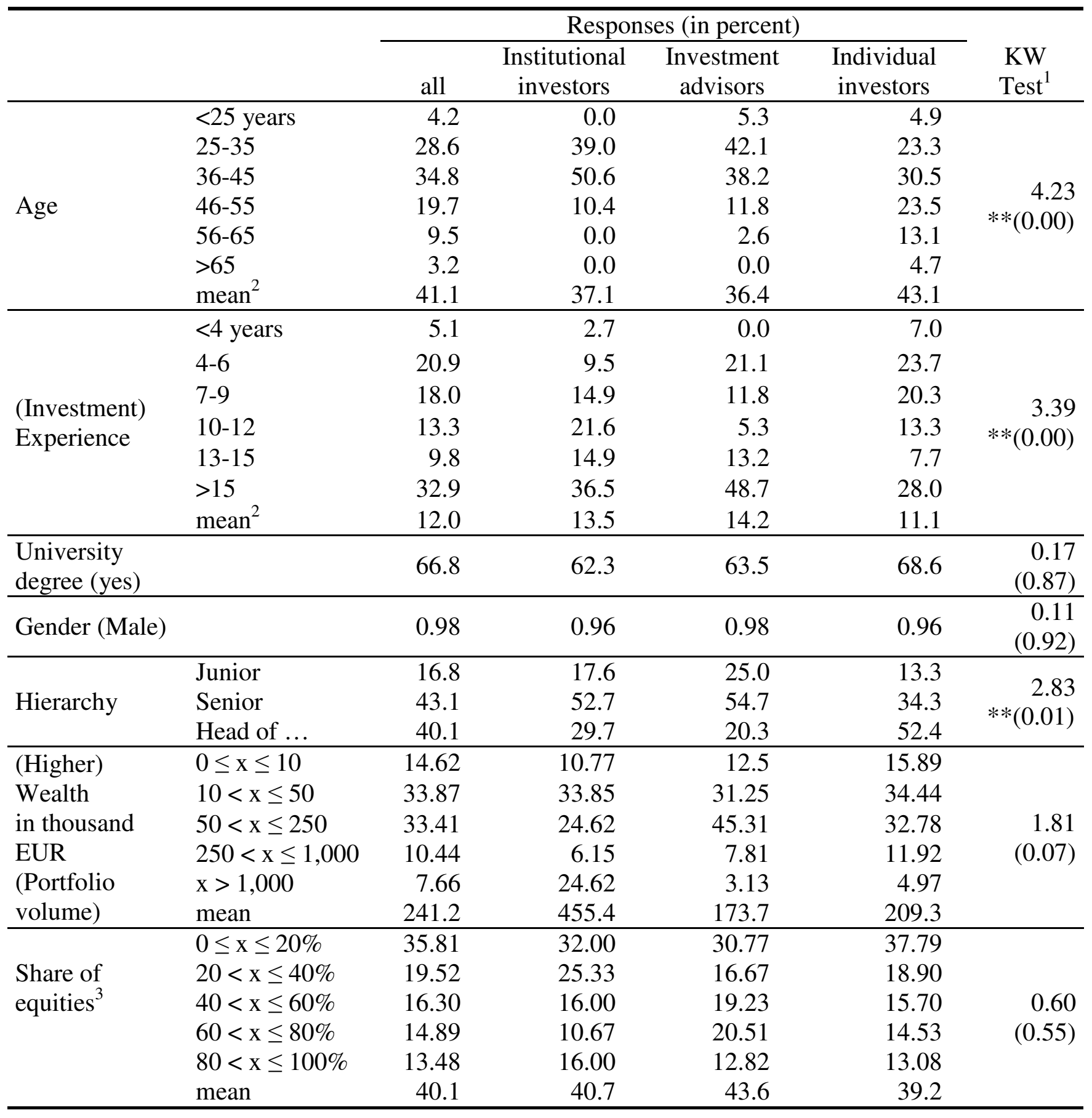

Notes: This table shows background characteristics for the three investor groups in our sample. We provide information on the frequency of answers for all questionnaire items with more than one category. For example, investors could choose one of six categories for their age and the distributions of answers for these six categories are shown in the table for all investors and separated for the three groups.

${ }^{1} \mathrm{KW}$ presents the Kruskal Wallis test statistic of the Null that there is no difference between the three investor group's answers. Stars refer to the level of significance: ***: $1 \%, * *: 5 \%, *: 10 \%$.

${ }^{2}$ Mean values are calculated assuming that values in the two open categories are 23 and 68 years, and 2 and 23 years of experience, respectively.

${ }^{3}$ Share of equities denotes the share of total investment volume that is invested in equities 


\section{Table 2. Description of further variables}

\begin{tabular}{|c|c|c|c|}
\hline & Item & Question, statement & Categories \\
\hline 1. & Higher turnover & $\begin{array}{l}\text { What is your annual turnover (sum of buy } \\
\text { and sell transaction volume) relative to the } \\
\text { total volume of your portfolio? }\end{array}$ & $\begin{array}{l}4 \text { categories }(1=<10 \% \\
2=10-25 \%, 3=25-50 \%, 4= \\
>50 \%)\end{array}$ \\
\hline 2. & $\begin{array}{l}\text { More } \\
\text { home bias }\end{array}$ & $\begin{array}{l}\text { Please allocate an amount of } 10,000 € \text { on } \\
\text { the following regions so that shares add up } \\
\text { to } 100 \text { percent. } 5 \text { regions: Germany, Europe } \\
\text { (ex Germany), USA and Canada, Asia, } \\
\text { Emerging Markets. }\end{array}$ & In percent between 0 and 100 . \\
\hline 3. & $\begin{array}{l}\text { Less reluctance } \\
\text { to loss } \\
\text { realization }\end{array}$ & $\begin{array}{l}\text { I generally wait for a price recovery of a } \\
\text { loss position, instead of selling this } \\
\text { position. }\end{array}$ & $\begin{array}{l}6 \text { categories from "complete } \\
\text { approval" (coded as } 1 \text { ) to } \\
\text { "complete disapproval" (coded } \\
\text { as } 6 \text { ) }\end{array}$ \\
\hline 4. & $\begin{array}{l}\text { Less disposition } \\
\text { effect }\end{array}$ & $\begin{array}{l}\text { I prefer to take profits when I am } \\
\text { confronted with unexpected liquidity } \\
\text { demands. }\end{array}$ & See item 3. \\
\hline 5. & $\begin{array}{l}\text { Less trend } \\
\text { Following }\end{array}$ & I generally follow the trend. & See item 3. \\
\hline 6. & $\begin{array}{l}\text { DAX/Dow Jones } \\
\text { return forecast } \\
\text { dummy }\end{array}$ & $\begin{array}{l}\text { Please estimate the development of the } \\
\text { DAX/Dow Jones over the next month. }\end{array}$ & $\begin{array}{l}\text { Point forecast. Coded as " } 1 \text { " if } \\
\text { DAX/Dow Jones index is } \\
\text { expected to increase and " } 0 \text { " } \\
\text { otherwise. }\end{array}$ \\
\hline 7. & Less risk averse & $\begin{array}{l}\text { Please classify your personal risk taking: } \\
\text { With respect to professional investment } \\
\text { decisions, I mostly act... }\end{array}$ & $\begin{array}{l}6 \text { categories from "very risk } \\
\text { averse" (coded as 1) to "little } \\
\text { risk averse" (coded as 6) }\end{array}$ \\
\hline 8. & $\begin{array}{l}\text { Longer forecasting } \\
\text { horizon }\end{array}$ & $\begin{array}{l}\text { What is your typical personal forecasting } \\
\text { horizon when making investment } \\
\text { decisions? }\end{array}$ & $\begin{array}{l}5 \text { categories from "Days" (coded } \\
\text { as 1), "Weeks", 2-6 Months", } \\
\text { "6-12 Months" to "Years" } \\
\text { (coded as 5) }\end{array}$ \\
\hline 9. & $\begin{array}{l}\text { Less domestic } \\
\text { information } \\
\text { advantage }\end{array}$ & $\begin{array}{l}\text { As a domestic investor I benefit from better } \\
\text { information compared to foreign market } \\
\text { players. }\end{array}$ & See item 3. \\
\hline 10. & $\begin{array}{l}\text { Higher DAX } \\
\text { optimism }\end{array}$ & $\begin{array}{l}\text { Please estimate the development of the } \\
\text { DAX within the next month. }\end{array}$ & $\begin{array}{l}\text { Point forecast (converted into } \\
\text { return forecast). }\end{array}$ \\
\hline
\end{tabular}

Notes: This table details items asked for in the survey. For each item we provide the specific question or statement and possible answers in the survey. As an example, investors were asked for their portfolio turnover (item 1). The exact question was "What is your annual turnover (sum of buy and sell transaction volume) relative to the total volume of your portfolio?" (third column) and answers could be given by checking a box at one of the four categories indicated in column four of this table, i.e. less than $10 \%$ p.a., $10-25 \%$ p.a., $25-50 \%$ p.a., or more than $50 \%$ p.a.. 
Table 3. Responses in percent and descriptive statistics

\begin{tabular}{|c|c|c|c|c|c|c|}
\hline Item & & all & $\begin{array}{l}\text { Institutional } \\
\text { investors }\end{array}$ & $\begin{array}{c}\text { Investment } \\
\text { advisors }\end{array}$ & $\begin{array}{c}\text { Individual } \\
\text { investors }\end{array}$ & $\begin{array}{l}\text { KW } \\
\text { Test }^{1}\end{array}$ \\
\hline 1. Higher turnover & Mean & 43.45 & 38.12 & 43.70 & 44.62 & $\begin{array}{r}2.47 \\
(0.29) \\
\end{array}$ \\
\hline $\begin{array}{l}\text { 2. More } \\
\text { home bias }\end{array}$ & Mean & 29.65 & 19.18 & 31.75 & 31.45 & $\begin{array}{r}23.28 \\
* * *(0.00) \\
\end{array}$ \\
\hline $\begin{array}{l}\text { 3. Less reluctance to } \\
\text { loss realization }\end{array}$ & Mean & 3.97 & 4.34 & 3.77 & 3.94 & $\begin{array}{r}6.05 \\
*(0.05) \\
\end{array}$ \\
\hline $\begin{array}{l}\text { 4. Less disposition } \\
\text { effect }\end{array}$ & Mean & 3.62 & 3.74 & 3.49 & 3.62 & $\begin{array}{r}0.91 \\
(0.63) \\
\end{array}$ \\
\hline $\begin{array}{l}\text { 5. Less trend } \\
\text { following }\end{array}$ & Mean & 3.26 & 3.04 & 3.43 & 3.27 & $\begin{array}{r}2.96 \\
(0.23) \\
\end{array}$ \\
\hline $\begin{array}{l}\text { 6a. DAX return } \\
\text { forecast dummy }\end{array}$ & Mean & 0.51 & 0.54 & 0.49 & 0.51 & $\begin{array}{r}0.22 \\
(0.81)\end{array}$ \\
\hline $\begin{array}{l}\text { 6b. DJ return } \\
\text { forecast dummy }\end{array}$ & Mean & 0.35 & 0.32 & 0.24 & 0.39 & $\begin{array}{r}6.12 \\
* *(0.05) \\
\end{array}$ \\
\hline \multirow{6}{*}{ 7. Less risk averse } & Very risk averse & 0.65 & 0.00 & 1.32 & 0.63 & \multirow{6}{*}{$\begin{array}{r}0.52 \\
(0.77)\end{array}$} \\
\hline & 2 & 9.68 & 8.11 & 7.89 & 10.48 & \\
\hline & 3 & 15.05 & 22.97 & 14.47 & 13.33 & \\
\hline & 4 & 20.86 & 21.62 & 19.74 & 20.95 & \\
\hline & 5 & 35.27 & 27.03 & 38.16 & 36.51 & \\
\hline & Little risk averse & 18.49 & 20.27 & 18.42 & 18.10 & \\
\hline \multirow{5}{*}{$\begin{array}{l}\text { 8. Longer forecasting } \\
\text { horizon }\end{array}$} & Days & 14.88 & 9.33 & 11.69 & 16.87 & \multirow{5}{*}{$\begin{array}{r}6.41 \\
* *(0.04)\end{array}$} \\
\hline & Weeks & 22.73 & 18.67 & 15.58 & 25.30 & \\
\hline & 2-6 months & 31.20 & 37.33 & 36.36 & 28.61 & \\
\hline & 6-12 months & 18.60 & 22.67 & 20.78 & 17.17 & \\
\hline & Years & 12.60 & 12.00 & 15.88 & 12.05 & \\
\hline \multirow{6}{*}{$\begin{array}{l}\text { 9. Less domestic } \\
\text { information } \\
\text { advantage }\end{array}$} & Complete approval & 2.70 & 2.78 & 3.90 & 2.40 & \multirow{6}{*}{$\begin{array}{r}6.33 \\
* *(0.04)\end{array}$} \\
\hline & 2 & 16.80 & 22.22 & 20.78 & 14.71 & \\
\hline & 3 & 26.76 & 20.83 & 35.06 & 26.13 & \\
\hline & 4 & 18.46 & 25.00 & 11.69 & 18.62 & \\
\hline & 5 & 20.95 & 15.28 & 19.48 & 22.52 & \\
\hline & Complete disapproval & 14.32 & 13.89 & 9.09 & 15.62 & \\
\hline \multirow{4}{*}{$\begin{array}{l}\text { 10. Higher DAX } \\
\text { optimism }\end{array}$} & Mean & -0.72 & -0.25 & -0.88 & -0.79 & \multirow{4}{*}{$\begin{array}{r}1.16 \\
(0.56)\end{array}$} \\
\hline & Standard deviation & 4.83 & 4.50 & 4.50 & 4.99 & \\
\hline & Skewness & -0.68 & -0.54 & -1.06 & -0.62 & \\
\hline & Kurtosis & 5.53 & 3.37 & 6.52 & 5.63 & \\
\hline
\end{tabular}

Notes: This table provides information about investors' answers to questions and statements relating to their investment behavior. Questions not covered in Figure 1 are shown in more detail. ${ }^{1}$ The test statistic reported for the DAX return forecast dummy (item 6) corresponds to a t-test of equal means and not the Kruskal-Wallis test for equal medians across groups.

Stars refer to the level of significance: $* * *: 0.01, * *: 0.05, *: 0.10$ 
Table 4. Determinants of sophisticated investment behavior

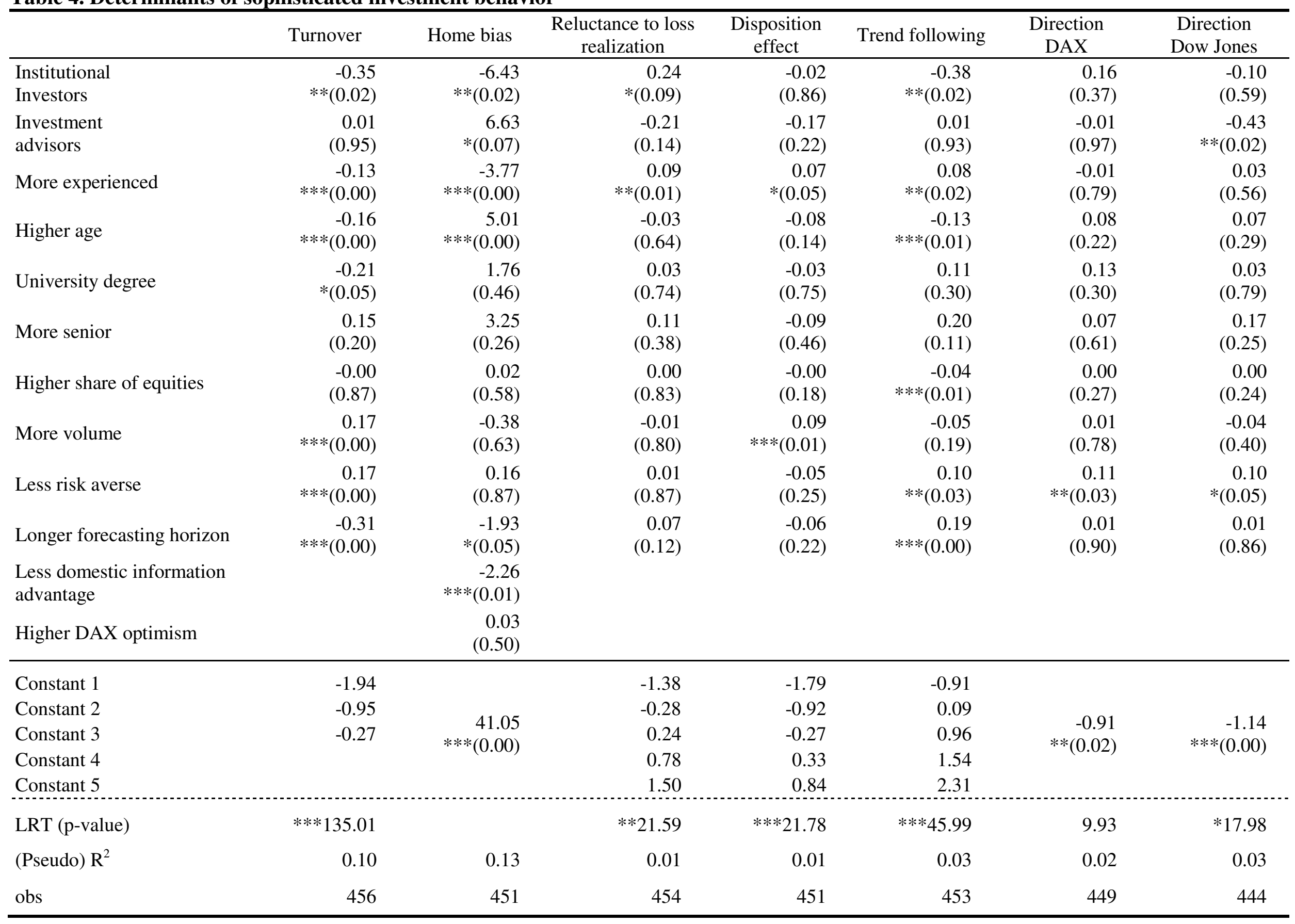




\begin{tabular}{lrrrr}
\hline & \multicolumn{5}{c}{ Turnover } \\
& \multicolumn{1}{c}{ Low } & \multicolumn{1}{c}{$2^{2}$} & \multicolumn{1}{c}{3} & \multicolumn{1}{c}{ High } \\
\cline { 2 - 5 } Inst. Inv. & 5.12 & 6.23 & -0.20 & -11.16 \\
Inv. Adv. & 0.52 & 0.75 & 0.05 & -1.34 \\
Prob(uncond.) & 8.02 & 26.03 & 26.37 & 39.58
\end{tabular}

\begin{tabular}{lrrrrrr} 
& \multicolumn{7}{c}{ Reluctance to loss realization } \\
& Approval & \multicolumn{1}{c}{2} & \multicolumn{1}{c}{3} & \multicolumn{1}{c}{4} & \multicolumn{1}{c}{5} & Disapproval \\
\cline { 2 - 7 } Inst. Inv. & -1.31 & -5.12 & -2.55 & -0.57 & 2.92 & 6.62 \\
Inv. Adv. & 1.48 & 4.71 & 1.80 & -0.16 & -2.97 & -4.88 \\
Prob(uncond.) & 2.72 & 17.81 & 17.62 & 21.25 & 23.61 & 16.99
\end{tabular}

\begin{tabular}{lrrrrrr} 
& \multicolumn{7}{c}{ Disposition effect } \\
& Approval & \multicolumn{1}{c}{2} & \multicolumn{1}{c}{3} & \multicolumn{1}{c}{4} & 5 & Disapproval \\
\cline { 2 - 7 } Inst. Inv. & 0.30 & 0.47 & 0.20 & -0.15 & -0.29 & -0.53 \\
Inv. Adv. & 2.27 & 3.39 & 1.20 & -1.26 & -2.07 & -3.54 \\
Prob(uncond.) & 6.10 & 18.73 & 24.31 & 22.75 & 24.43 & 13.67
\end{tabular}

\begin{tabular}{lrrrrrr} 
& \multicolumn{7}{c}{ Trend following } \\
& Approval & \multicolumn{1}{c}{2} & 3 & \multicolumn{1}{c}{4} & \multicolumn{1}{c}{5} & Disapproval \\
\cline { 2 - 7 } Inst. Inv. & 5.62 & 8.26 & -0.30 & -4.78 & -5.81 & -2.99 \\
Inv. Adv. & -0.14 & -0.26 & -0.04 & 0.13 & 0.19 & 0.11 \\
Prob(uncond.) & 6.14 & 23.41 & 33.32 & 19.06 & 13.41 & 4.67
\end{tabular}

\begin{tabular}{lccc} 
& $\begin{array}{c}\text { Direction DAX } \\
\text { Correct direction }\end{array}$ & & $\begin{array}{c}\text { Direction DJ } \\
\text { Correct direction }\end{array}$ \\
\cline { 2 - 3 } Inst. Inv. & 6.09 & -3.66 \\
Inv. Adv. & -0.41 & -13.91 \\
Prob(uncond.) & 50.90 & 34.38 \\
\hline
\end{tabular}

